\title{
Overview of Islamic Financial System and its Efficiency
}

\author{
Miad Nakhavali \\ $\mathrm{PhD}$ Student of International Politics \\ Faculty of Political Sciences, University of Belgrade, Serbia
}

doi: 10.19044/esj.2017.v13n19p108 URL:http://dx.doi.org/10.19044/esj.2017.v13n19p108

\begin{abstract}
This essay attempts to discuss the principles of Islamic financial system based on Sharia law and its efficiency in the real world. It is achieved by overlooking different methods of Islamic financial and banking system. The focus of the essay is on the examination of Islamic financial system and its approaches in the Islamic countries, especially those shariabased law countries. Sharia law is based on the Holy Book of Muslims Quran and on the traditional teaching of Prophet Muhamad in the so called Sunnah. Even the most restricted Islamic banks are using conventional banking methods under the cover of Islamic slogans. Despite these methods, the share of Islamic banks when compared with conventional ones is extremely low. The other inefficacy of Islamic banks involves reducing customer's freedom by prohibiting all interest-methods and giving them some dictated options only.
\end{abstract}

Keywords: Islamic Financial System, Conventional banking System, Sharia Law

\section{Introduction}

This essay attempts to discuss the principles of Islamic financial system based on Sharia law and its efficiency in the real world. It is achieved by overlooking different methods of Islamic financial and banking system. The focus of the essay is on the examination of Islamic financial system and its approaches in the Islamic countries, especially those shariabased law countries. Sharia law is based on the Holy Book of Muslims Quran and on the traditional teaching of Prophet Muhamad in the so called Sunnah.

Many observe Islamic economy as an insufficient and incapable system which only has the brand of "Sharia law". In fact, it follows the conventional banking rules. On the other hand, many thinkers consider 
Islamic economy as the useful alternative among capitalism and socialism. Bhindi Ardito considers the insufficiency of Islamic economy from the Muslim's poor understanding and wrong interpretation of the Sharia financial system. He notes: "because many Muslims lack the knowledge about Riba (usury), when they expand their business, they prefer transaction in conventional bank to transaction in Sharia bank. As a result, market share of Sharia banking become lower than conventional banking despite Muslim is a majority in a country."

Some consider Islamic financing system as a prohibition-driven industry. Prohibition in Islamic economy includes the following: Riba (usury), Gharar (Uncertainty), Maysir (gambling), and some forbidden products and industries.

Thus, the question which draws our attention is on whether the Islamic countries are fully implementing sharia-based financial law or not. Many observed that the Islamic financial system is not really following sharia law, but they are trying to use it only as a brand to satisfy Muslim customers. Volker Nienhaus notes: "no modern states in the Muslim world has practically implemented an Islamic economic system, perhaps with the exception of Sudan and Iran.",

\section{Background}

With the emerging of the decolonization of Islamic countries in the second half of the $20^{\text {th }}$ century, Muslim thinkers and philosophers attempted to codify Islamic financial system. Also, they aim to criticize capitalism and its banking principle as Haram (forbidden). Since then, Muslim leaders has placed emphasizes on Islamic economic system. This is because they believed one important way to set their country free from the western dominance was to establish a sharia-based economy.

According to the rapid growth of the Muslim population around the world to 2 billion and the establishment of many Islamic banks from Africa and Middle East to Asia, it is necessary to understand the principles and, more importantly, the implementation of these principles in the real world. Muhammad Hanif in Islamic and conventional banking points to the basic contradiction of conventional banking system and Islamic banking system. He notes "as the conventional banks are established under the principles of capitalism and transact business by charging interest, which is unacceptable (forbidden) in Islamic law, so Muslims left with no choice except to establish their own financial institution under Islamic principles."

Consequently, there are also many obstacles on the path of Islamic economy. One of the main problem is the lack of consensus over the principles and the different interpretation of Sharia law i.e. Iranian Sharia- 
based banking system has different implementation compared to Indonesian or Pakistani ones. These differences and contradictions in Islamic financial system led to significant low market share of sharia banking system compared to conventional banking system. This is how Ali-Al Jabri explains Islamic banking and finance:" Islamic banking and finance can be described as a system through which finance is provided in the form of money in return for either equity or rights to share in future business profits, or in the form of goods and services delivered in return for a commitment to repay their value at a future date".

In the next parts we will attempt to indicate different principles of Islamic banking system and finance. As well as exploring some of the practical examples of the Islamic finance in the real world and the extent of its success.

\title{
Principles of Islamic Economics
}

Islamic economics' prohibitions include the following: Riba (Usury): The action of lending someone money on the condition of Charging high rate
interest.

Prohibitions

\begin{abstract}
$\longrightarrow$ Gharar (Uncertainty): when two partners are entering into the contract and the partner lacks enough information about the contract. Also, it could be translated to mean delude or cheat.
\end{abstract}

Maysir (gambling): acquisition of money by luck and transaction which refers to gambling or betting.

Forbidden products and industries: Islam considers products such as: alcohol, pork, pornography, and other receiving income through gambling such as "haram" which was prohibited.

Even with these prohibitions, some Islamic banks do not consider interest seeking in some occasions as Riba. Therefore, this lack of consensus between Islamic banks led to a slow growth of them even in Islamic countries.

\section{Islamic Finance}

Since receiving interest in Islamic banking system is forbidden, they need to offer interest-free methods. Basically, there are two type of banking 
methods; partnership method and return structure method. Islamic banks are also offering the Islamic insurance which is so called Takaful, repayment in the case of loss to individuals or companies. Muslim jurists conclude that insurance in Islam should be based on principles of mutuality and cooperation. In addition, it should encompass the elements of shared responsibility, joint indemnity, common interest, and solidarity.

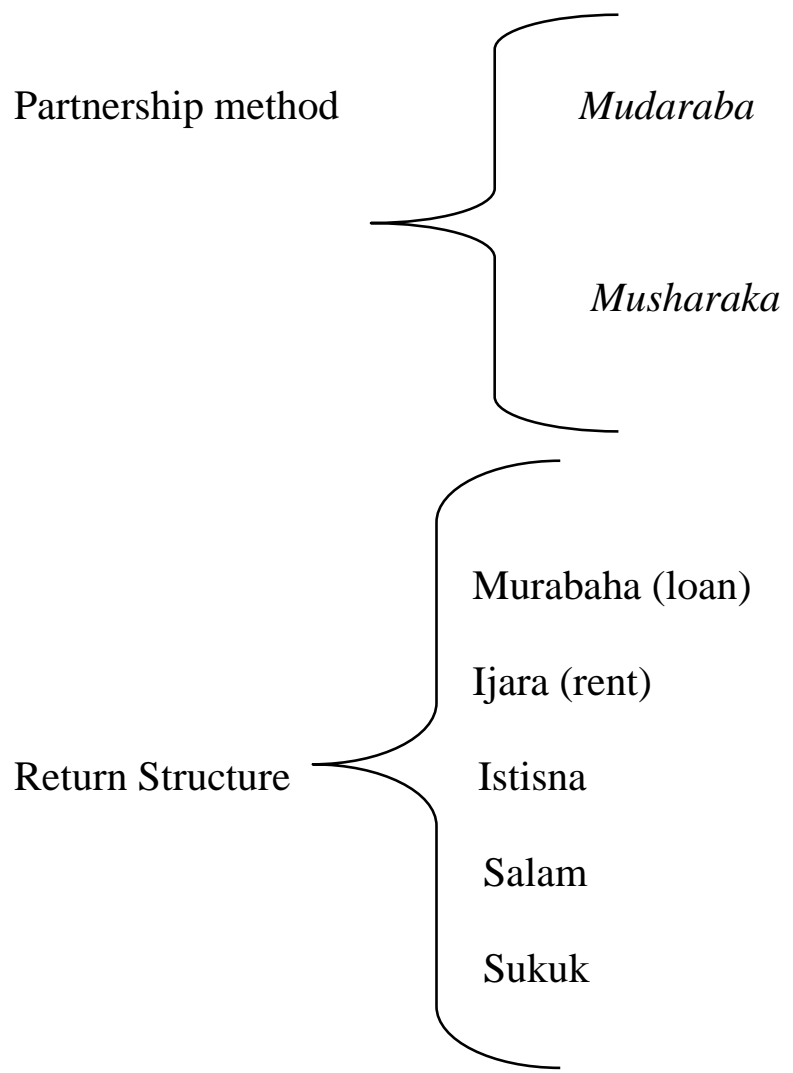

\section{Musharaka}

This agreement is based on partnership which conjugates share cash or non-cash belonging to multiple natural and legal persons with the purpose of increasing benefit. So in this method, both parties enjoy benefit and loss of investing.

\section{Mudaraba}

It is a contract between two parties where investor transacts capital to the entrepreneur in order to increase interest. However, the profit share is on the basis of the predetermined contract between two parties. This method is based on the mutual trust and is used more as private investment. In the case of loss, entrepreneur is not obliged to pay compensation. As this method is a branch of partnership, it requires a 
close cooperation and working relationship between investor and entrepreneur.

\section{Murabaha}

It is a method whereby the seller purchases commodity and goods outright, and then attempt to sell them a bit more expensive than the purchase price to the customers. The deal could be in cash or credit (installment). Therefore, it could be defined as a kind of loan in the conventional banking system.

\section{Ijara}

This contract could be defined as a rent or leasing system, in which one party purchase the accommodation. Instead of selling it to the customer, it is rented to him/her in order to use his/her assets. Therefore, it is_described as lessor/lessee contract.

Istisna: It is an investment for future manufacturing or construction. Here, the investors pay in advance for future delivery of manufactured goods, construction, assets etc. After the development of the production or project, investors can utilize the assets in other Islamic ways that were discussed earlier such as Ijara (rent) etc.

Salam: It could be considered as a branch of Murabaha with the difference of advance paying for future delivery of assets. In this method, customers receive discount for advance payment. It is more used for agriculture and manufacturing purposes.

Sukuk: This is another Islamic instrument which uses Islamic bonds. This method is more like a stock exchange in conventional economic system. The difference is that in Sukuk, the ownership of the asset belongs to the sukuk holder with all its benefit and loss. In conventional system, bonds represent debt obligation of the issuer, while conventional equities represent ownership interest in the issuer itself (Rdeshir Atai).

\section{Zakat (Distribution of Wealth)}

Zakat is one of the fundamental religious obligation of Muslims which in its translation from Arabic could mean purification. Muslim believes that their wealth or property belongs to Allah. As such, a Muslim must purify his/her wealth according to the will of Allah. According to Islamic regulations, Zakat is $2.5 \%$ of one year's total cumulative wealth. This amount is then distributed to the poor. Many consider Zakat as a type of taxing system, although Muslim observes it as a spiritual act to assist the poor and those who are in need. It is not seen as a requirement of secular law. Subsequently, the difference is that the government cannot use Zakat for general budget. 
Zakat system could be performed by the state if Muslims are reluctant to pay zakat voluntarily. In most of the Islamic countries such as Iran, Bahrain, Bangladesh and Egypt, Zakat is voluntary. However, in some countries like Libya, Pakistan and Malaysia, Zakat paying is mandatory. Furthermore, in other countries such as Afghanistan, Algeria and Azerbaijan, there is no government system for Zakat. Again, based on many other issues, Muslims do not have a consensus over Zakat. Thus, there are different interpretations of obliged person (Muslim) who needs to pay Zakat. Prophet Muhamad listed that the following product must be subjected to Zakat:

Camel, sheep and cows

Gold, Silver and coins

Wheat, barley, dates and grapes

Buried Treasure

Furthermore, the question that was raised here is that should Muslims generalize these examples and consider, for instance, the third category as all who are engaging in agriculture? On the other hand, the Prophet only points to specific ownership of these products. After the death of the Prophet, some redefined these categories again. For example, rice and some other productions were added later to the list of Zakat payment.

\section{Sharia-Law Economy in Action (South Asia, Iran, and Pakistan)}

Indonesia: Although it is the world's most populous Muslim country, it seems that there is less tendency toward Islamic Banking system in this country and also south Asian countries. For instance in Malaysia and Indonesia (which have been criticized always for having very liberal interpretation to Sharia law), mark-up instruments were used as a back door instead of share profit-loss. Although Indonesia is the biggest Muslim country, it only has three Islamic banks based on Sharia law. Thus, the performance of these banks when compared with the conventional bank proved the insufficiency of them.

Iran: After the Islamic revolution of Iran, government attempted the total islamization and state control over the economy. Thus, it seems that Iranian officials are reluctant to publish the annual data reports of Islamic transactions. In fact, this is because Iranian economy like other Middle East countries is utilizing mark-up instruments. Hence, restrictions and limitations which were imposed by the government led to numerous corruptions that Iranian economy is faced with. 
Pakistan: The Islamization in Pakistan is pretty much gradual compared to Iran. However, both Iranian and Pakistani governments have restricted regulation in their economic system. It seems that the performance of Pakistani bank when compared with the conventional ones were so poor except that of SC Modaraba bank. This bank had a bit of better performance, while two others, Meezan and Al Baraka, had a very low share. The Pakistani Banks are also using a mark-up instrument in order to raise more benefit which is considered as haram (forbidden) in Islam.

In addition, these banks were named as an Islamic bank which is supposed to be based on Sharia law. In practice, there are many conventional banking methods used by Islamic banks. However, what is so surprising is that among Islamic banks, the best performer is among the most liberal ones. Ondrej Sramek, in his work on Islamic economy, notes: The top-performers are Islamic Banks in Indonesia, which are often considered too liberal in interpreting Islam.

\section{Advantages and Disadvantages of Islamic Financial System}

Islam expect Muslims to trade based on profit-loss and partnership. Therefore, this should lead to better performance of the economy. If these principles could really be implemented, then we could expect:

- $\quad$ No speculative trading or cheating

- $\quad$ Reduction of uncertainty

- $\quad$ No mark-up and interest seeking

- $\quad$ No excessive leverage

However, if for any reason, the government and officials are not able to perform the Sharia law as it is claimed, then it could have the reverse result. By the way, inherent Sharia law includes many restrictions such as:

No activity which is prohibited by Sharia law irrespective of its profitability or loss such as pornography, pork, alcohol, and other forbidden productions.

No lending of cash which is not fulfilling one of the Islamic investing methods discussed earlier.

No clear logic as to why only profit could be shared after the development of investing in Mudaraba or other kind of Islamic trade; hence, loss needs to be shared too.

\section{For Further studies}

As the whole idea of Islamic Banking and finance is to prevent cheating and to increase equality and benefit of both sides it would be helpful for further studies to explore the ways in which Islamic Banking could implement its real principles. Furthermore in order to have a more realistic and clear picture of Islamic Financial system we need to examine 
the obstacles that this system is facing in the modern and technological world.

\section{Conclusion}

In conclusion, we attempted to discuss the principles of Islamic financial system based on Sharia law and its efficiency or inefficiency in the real world. This is done by overlooking different methods of Islamic financial and banking system. Many Islamic countries are performing Sharia law based on the Holy Book of Muslims Quran and on the traditional teaching of Prophet Muhamad in the so called Sunnah. Therefore, it seems that in practice, Islamic economic system is facing a lot of obstacles.

By overlooking some very restrictive and regulated economy such as in Iran and Pakistan and the most liberal one such as Indonesia, the results surprisingly show the better performance of Indonesian Islamic banks. It seems that even the most restricted Islamic banks are using conventional banking methods under the cover of Islamic slogans. Even with these methods, the share of Islamic banks when compared with conventional ones is extremely low. The other inefficacy of Islamic banks is reducing customer's freedom by prohibiting all interest-methods based and giving them only some dictated options. It is even worse in some Islamic countries that there is no other option except Islamic financial system on the table. Consequently, it could not be described whether the Islamic banks perform better or worse when there are no conventional banks at all.

\section{References:}

1. Ardeshir Atai. Overview of Islamic Financial investments.

2. Bhinadi Ardito. Sharia Economics Not Only Sharia Financial Institution.

3. James M Garner. A Critical Perspective on the Principles of Islamic Finance Focusing on Sharia Compliance and Arbitrage.

4. Muhammad Hanif. Differences and Similarities in Islamic and Conventional Banking.

5. Mahmoud A. El-Gamal. Limits and Dangers of Sharia Arbitrage, Rice University.

6. Nicholas HD Foster. Islamic Commercial Law: An Overview.

7. Ondøej Šrámek. Islamic Economics: New Economic Paradigm, or Political Agenda?

8. Timur Kuran. The Rule of Law in Islamic Thought and Practice: A Historical Perspective.

9. Volker Nienhaus. Fundamentals of an Islamic Economic System compared to the Social Market Economy.

10. http://www.islamic-banking.com/takaful_insurance.aspx 3.23.2016 
11. https://www.muslimaid.org/zakat-charity/

12. https://moneyjihad.wordpress.com/2010/08/09/zakat-by-country/

13. http://www-stud.rbi.informatik.uni-

frankfurt.de/ osman/IslamicBankingandFinance.pdf 